13. Nikolai', G. Ju. (2008). Rozvytok muzychnopedagogichnoi' osvity v Pol'shhi (HH stolittja). Kyiv: IPOOD APN Ukrai'ny, 48, 2-3.
14. Zjazjun, I. A. (1996). Gumanistychna paradygma v osviti. Vyshha osvita v Ukrai'ni: realii', tendencii', perspektyvy rozvytku. Kyiv, 9.

Дата надходження рукопису 17.08.2015

Отич Олена Миколаївна, доктор педагогічних наук, професор, Науково-дослідний інститут ДВНЗ «Університет менеджменту освіти» НАПН України, вул. Артема, 52-а, м. Київ, Україна, 04053

E-mail: ndi-direktor@ukr.net

УДК 37.014

DOI: $10.15587 / 2313-8416.2015 .50831$

\title{
IMPLEMENTATION OF THE HIGHER EDUCATION LAW OF UKRAINE IN THE POSTGRADUATE EDUCATION SYSTEM
}

\author{
(c) N. Klyasen, N. Goncharenko
}

According to the title in the article describes innovative norms of the "Higher Education Law of Ukraine", concerning post-diploma pedagogical education.

In particular, it is specially noted the main issues that could be implemented in the relevant legal acts regarding the functioning post-diploma pedagogical education

Keywords: post-diploma education, educational reform, modernization of the educational sector, conceptual basis of modernization of higher education

В соответствии с названием, в статье описываются инновачионные нормы "Закона Украины о высшем образовании", касающиеся последипломного педагогического образования.

В частности, специально отмечаются основные вопросы, которые могли бы быть реализованы в соответствующих правовых актах, касающихся функиионирования последипломного педагогического образования

Ключевые слова: последипломное образование, реформа системы образования, модернизация образовательной сферы, концептуальные основы модернизации высшего образования

\section{Introduction}

The Draft Law on Higher Education was developed about three years ago in 2012 developed by a working group headed by the rector of the National Technical University of Ukraine "Kyiv Polytechnic Institute" Mykhailo Zhurovsky. He is already the principal author of the newly adopted law. The authors explained that the current law is the result of many publicity discussions and lots of remarks and suggestions that came from universities and education experts who supported the higher education in Ukraine.

"It is important that this law was the law of consensus. In his own it's revolutionary, reformatory, because it involves many important changes, which all have been waiting for. We supported by the society, the government, parliament and the president. Exactly so done the educational reform" - commented on the adoption of the Law Minister of Education and Science of Ukraine Sergey Kvit [4].

The Law of Ukraine "On Higher Education" launches a new stage of development of Ukrainian higher education, because it is a pro-European in nature, democratic and contains a number of progressive standards. It reflects modern trends in higher education in the context of European education environment, modern society needs, interests for the real quality of higher education in the country and formation of our competitive educational system for the entry into the European Union. This law is very important for the further development of education in Ukraine.

\section{Analyzing and problem statement}

Implementation of the law is to overcome serious problems in training that inherited Ukrainian of education from of the former Soviet Union. Primarily it comes to so-called "sectoral" Referrals of higher education when universities were forced to prepare specialists for specific branches of national economy. And also the system advanced training, based on the principles of appointment and voluntary-compulsory attraction the teaching staff. The adoption of the Law - is a significant achievement, which is the first state's step towards to European standards of higher education, because it contains a lot of rules that have long been introduced in the European educational space. [1]

\section{Problem statement}

Implementation of the above-mentioned law is a long gradual process. So, the main task today must be mobility - constant movement, research and summarize the changes occurred almost daily [1].

To this end, the Ministry of Education and Science of Ukraine offers to the public site where anyone can find timely and useful information by the link below http://osvita.gov.ua/, has the opportunity to participate in an open discussion of various provisions of the Act and 
regulations necessary for its implementation of making constructive comments and suggestions.

Implementation of the Law "On Higher Education" will take place in three stages:

the first - forming system by-laws without which we can move forward: decrees, resolutions, regulations. At the first stage, universities and educational community can do a lot by offering the Ministry of Education and Science of Ukraine their own vision of implementation concerning of the changes that belongs bring in activities of higher education institutions envisaged by this Law;

the second - should be started in September 2015, when will work the National Agency with the quality of higher education. Also, this time the transition is to take place at maximum load teachers from 900 to 600 hours a year. And reduce the number of credit hours from 36 to 30 . This means that in the distribution of time for training courses under the new educational standards, changes take place. In addition, students will have an opportunity to choose up to $25 \%$ of courses that will significantly enhance the competition among teachers;

the beginning of the third phase should be considered the beginning of 2016, when there are come into effect the transitional provisions of the law, norms implementation of which needs to lengthy preparation and additional funding. [5]

The Law of Ukraine "On Higher Education" has an innovative character. Considering of foreign experience and at a modern level in it is:

- the types of higher educational institutions universities, academies, college and vocational college and necessary conditions their functioning. Institute accordance with international norms defined as a structural unit of the higher educational establishments;

- normalized questions standards of higher education. Formatting the list of specialties for educationalqualification levels (junior specialist, bachelor, master) and educational, scientific and research levels (Doctor of Philosophy, Doctor of Science) reserved for the competence the Ministry of Education, which will respond more better to the needs and challenges of industries and national economy;

- found that state order will extend only to those higher educational establishments that provide qualitative education;

- the new independent state institution - the $\mathrm{Na}$ tional agency of education quality assurance begins to operate next year. Results of its operations will stimulate institutional leaders to fight for resources that the state should allocate to each of them in education; we note that part of the agency will include representatives of MES of Ukraine, higher educational institutions of different ownership forms, National Academy of Sciences of Ukraine, employers, etc.;

- the Parliament of Ukraine will be introduced a bill on only one scholarship fund and pay scholarships to students who really deserve it, having the strong performance in learning, otherwise the scholarship has become a social benefit as it actually is now, one of the effective tools stimulate students to study [3].

The New Law greatly expands the autonomy the rights of higher education institutions and for example from now they can independently dispose of their own finances, address issues of educational process organization internal governance, economic and other activities.

The basis of the Law put the conceptual foundations of modernization of higher education by introducing modern tiered its organization according to a National Qualification Framework. Henceforth higher education be carried out at the following levels:

- Initial level (short cycle) of higher education

- First (bachelor) level of higher education

- The second (master's) level of higher education

- Third (educational-scientific) of higher education

- Scientific level of higher education.

Obtaining higher education on each level involves successful execution corresponding educational (education-vocational and education-research) or the scientific program, which is the basis for the award of the respective degree of higher education:

1) Junior Bachelor;

2) Bachelor;

3) Master;

4) Doctor of Philosophy;

5) $\mathrm{PhD}$.

In this way creates the necessary conditions for the feasibility international educational and scientific projects, academic mobility of teachers, researchers and students; ensuring equality under the law in rights of higher educational institutions of all forms of ownership and the teaching staff.

Considerably expanded the state guarantees for relation equal access of citizens to higher education. Envisaged obligation of higher education institutions for the creation of appropriate conditions entry and training of people with special needs. Bringing the buildings, structures and premises of higher education institutions in compliance with the accessibility requirements of individuals with special education needs.

Innovation is also the establishing the National Agency for quality assurance for higher Education of Permanent collegial body authorized by law to control the implementation of state policy in the field of quality of higher education.

The Law significantly expanded the powers of the student government and public control concerning the participation in the activities of higher education institutions and of educational process organization.

4. Statement the main material. Post-diploma education is specialized enhancement of education.

In the Law of Ukraine "On Higher Education" postgraduate education, professional development and training of teachers and teaching staff are considered as components of higher education.

Thus, the institutions of postgraduate education in accordance with item 1.7 of Article 1 of the Law attributed to the higher education institutions (p.1.16 the same article) - to educational activities. Therefore, all innovations of new norms of the Law "On Higher Education" related to postgraduate, including postdiploma education.

Many forces and the energy from the heads and scientific-pedagogical and educational groups Institu- 
tions of post-diploma teacher education, pedagogical community and others was spent on the preparation of comments and proposals to the draft Law of Ukraine "On Higher Education". It should be noted that much of the new law are taken into account. In its main part is done in 6 articles, including complete article 60 "Post-diploma education" and (p. 4. 2, a) of Chapter XV "Transitional and final provisions".

In p. 1 of Article 60 of the Law gives the following definition of Postgraduate Education:

"Post-diploma education is specialized enhancement of education and professional training of individuals through deepening, expansion and updating of their (professional) knowledge, skills (and) abilities (or acquisition of a different profession or specialization) on the basis of previously (attained level) of higher education (specialization) or vocational education (profession) and practical experience ${ }^{\prime \prime}$

The parentheses contain words and phrases which removed from the concept of Postgraduate Education, formulated in Article 47 of the current Law "On education", i. e. instead of "professional knowledge" is used only "knowledge", but omitted the words "or get another profession, specialty" and "attained level".

\section{Consequently:}

At the first, significantly is expanding the amount of knowledge that person can get in the course of postdiploma education: they must be not only professional, but also general education that would help the overall development of a person who retraining and / or improves skills;

At the second, to get another profession now and / or specialty does not belong to the functions and tasks of Post-diploma education Institutes, because this be engaged with the higher education institutions.

Individuals who receive the "additional or separate educational services, including programs of postdiploma education" under p. 3.1 of the Article 61 of the Law is classified as listeners.

In n. 20 Article 1 of the Law it comes about specialization as part of the specialty, defined higher education institution and foresees a profile specialized educational or vocational and scientific education and training program for candidates post-diploma education.

Post-diploma Institutes can be as individual agencies, as discussed earlier yet, and the structural units of higher education institutions, as referred to in $\mathrm{p}$. 7.3 of Article 33 of the Law. In facts stored current practice that, along with regional institutions of postdiploma education in Kiev operates with the same status Postgraduate Institute Borys Grinchenko Kyiv University.

In accordance with paragraph 3 of Article 60 of the Law "On Higher Education" scientific, educational and pedagogical workers can have traineeship not only in Ukraine but also abroad. It is clear that the implementation of such opportunities need to create the necessary conditions.

With all these changes to the Law of Ukraine "On Higher Education" "Final and transitory provisions" (p. 4. 2 of the Section XV) offer new version of Article 47 of the current Law "On Education", which defines:

1) the concept of "post-diploma education" its components (specialization, retraining, training and internship) in a slightly different order than is done in the law "On education";

2) forms of organization postgraduate education, among which are, along with traditional concepts of "internship" a number of new, somewhat unusual names, including "vocational training working professions for workers", "post-training", "medicine residency", "clinical residency";

3 ) in the last tenth paragraph of Article actually it comes about network of institutions which can provide the post-diploma education: academies, institutes of postgraduate education, vocational education, respective structural subdivisions of higher educational institutions, scientific, educational and research institutions in order approved by the Cabinet of Ministers of Ukraine.

So, the new Law "On Higher Education" provides sufficient legal framework for the post-diploma education and institutions that have to implement it. First of all, an implementation of the law in this respect needs to appropriate laws and by-laws that would regulate the functioning of the industry in modern conditions. Obviously, in general the first step must be a law of direct action or by-laws on the operation of post-diploma education. And the next it'll be standard-setting activities in support of the industry, including pedagogical and post-diploma education institutions.

As you know, the Action Plan of the Ministry of Education and Science of Ukraine to implement the Program of the Cabinet of Ministers of Ukraine and the Coalition Agreement is approved by the Ministry of Education and Science of Ukraine of 29.01.2015 № 63.

Unfortunately, among the 46 points of the Action Plan of the Ministry of Education on the implementation of the Law of Ukraine on July 1, 2014 p. № 1556-VII «On Higher Education" not found none in which it was directly used for post-diploma education, not to mention the post-diploma pedagogical education.

Although some of the regulations that the Ministry of Education and Science of Ukraine Cabinet of Ministers offer for approval, which are, in our opinion, a certain interest for institutions of postgraduate education as higher education institutions and can be implemented in future legislation.

In particular, the procedure for implementing the right to academic mobility and the election of the head of the university, the definition of standards of material and technical and financial provision order, issuing licenses for educational activities and accreditation, the full list of positions of scientific and pedagogical and pedagogic staff of higher education institutions, teacher qualification categories and titles of teaching staff, of paid educational and other services, which could be implemented in the relevant normative legal acts regarding the functioning of Postgraduate Pedagogical education. 
Unfortunately but over 20 years we have not managed to secure the rights of pedagogical and scientific and pedagogical workers to "the free choice program content, forms of learning and educational institutions, institutions and organizations engaged in advanced training and re-training" as provided by Article 55 of the Law "On Education".

These funds could be consolidated for all five years and pay rates based on one of the existing schools in Ukraine postgraduate education or alternative centers. It would consider the possibility of payment for participation in seminars or conferences and this should be counted as a form of training or retraining.

Any alternative under the domestic system of postgraduate education are still outlawed because local Attestation Commission take into account, as a rule, only official certificate from courses that the teacher "passed" on the basis of "his" Institute of Postgraduate Education.

\section{Results of research}

Thus, the above needs provide training on the provisions of postgraduate education in higher education.

No doubt that Ukraine needs a modern system of postgraduate education based on the principles of freedom to choose and liability for their own personal path selection professional development; a system that contribute to democratic teacher training developed critical thinking and elementary self-respect, capable build the partnerships in the world that is constantly changing. This requires not just partial modernization, but the deep systemic changes, the introduction of qualitatively new mechanisms in management of educational process organization funding and staffing of the Retraining System and advanced training of teachers.

The existing monopoly institutions of postgraduate education on advanced training and retraining of educational workers hinders the development of alternative forms of professional development. The main causes of this disadvantage are that:

- not everywhere recognized the official status of documents issued advisory and training centers, NGOs educators, educational programs and projects as needed to pass the certification documents obtained only in institutions of postgraduate education. Therefore, teaching staff, with certificates of leading Western educational management centers that now no longer a rarity, still have to get a formal "crust" of domestic institutions of postgraduate education - regional, Kyiv and the Central Institute of Postgraduate Education;

- kept current system of funding post-graduate teacher education, where local budgets, financing institution, do not provide funds for teacher professional development, although the principle of "costs follow the teacher" as that "funds follow the student" is not too difficult to implement. Simply annual budget of institutions of postgraduate education divided by the number of teachers in the region and multiply the result by five (the number of years between the planned certification). This teacher should have the right to independently determine how it will use the funds for their professional development [6].

\section{Conclusions}

We believe that the implementation of the Higher Education Law of Ukraine in the part of postgraduate education should:

- To form the current legislative and regulatory framework of functioning of postgraduate education and institutions which have carried out, taking into account European and international experience. The first step must be a law of direct action or regulations on the operation in general of post-diploma education, and the second - standard-setting activities to ensure of stuff teaching postgraduate education institutions;

- Upgrade educational and thematic plans and programs and their specialization in the context of modern requirements of education systems;

- Raise the individualization process training, provide alternative passage course training and retraining of teaching staff;

- Systematically carry out scientific research so as to identify monitoring needs and requirements of pedagogical workers and management personnel concerning education and training desired content relevant disciplines;

- Focus heads of state administration and local self-government system on the role of training in the modernization of the education system in Ukraine.

\section{References}

1. The Law of Ukraine "On Higher Education" [Electronic resource]. - The Verkhovna Rada of Ukraine; Law of 01.07.2014 № 1556-VII. - Available at: http://zakon4.rada. gov.ua/laws/show/1556-18

2. Babin, I. The National education glossary: higher education/auth [Text] / I. Babin, Y. Bolyubash, A. Garmash, et. al. Kyiv: LLC "The Publishing House "Pleiades", 2011. - 100 p.

3. Comparative analysis of draft laws on higher education [Text] / Y. Stadniy, I. Sovsun (Eds.). - Center for the study of society. - 39 p. - Available at: http://cedos.org.ua.

4. What changes carries the New Law of Ukraine "On Higher Education" [Electronic resource]. - Available at: http://ipress.ua/mainmedia/yaki_zminy_nese_novyy_zakon_ukr ainy_pro_vyshchu_osvitu_79856.html

5. Project: Implementation of the New Law of Ukraine "On Higher Education" [Electronic resource]. - Available at: http://osvita.gov.ua/?page_id=552

6. The Statute of the National Agency for Quality Assurance in Higher Education [Electronic resource]. - Available at: http://zakon4.rada.gov.ua/laws/show/244-2015-п

\section{References}

1. The Law of Ukraine "On Higher Education". The Verkhovna Rada of Ukraine; Law of 01.07.2014 № 1556-VII. Available at: http://zakon4.rada.gov.ua/laws/show/1556-18

2. Babin, I., Bolyubash, Y., Garmash, A. et. al. (2011). The National education glossary: higher education/auth. Kyiv: LLC "The Publishing House "Pleiades", 100.

3. Stadniy, Y., Sovsun, I. (Eds.) Comparative analysis of draft laws on higher education. Center for the study of society, 39. Available at: http://cedos.org.ua.

4. What changes carries the New Law of Ukraine "On Higher Education". Available at: http://ipress.ua/mainmedia/ yaki_zminy_nese_novyy_zakon_ukrainy_pro_vyshchu_osvitu_ 79856.html 
5. Project: Implementation of the New Law of Ukraine "On Higher Education". Available at: http://osvita.gov.ua/? page_id=552
6. The Statute of the National Agency for Quality Assurance in Higher Education. Available at: http://zakon4.rada.gov.ua/ laws/show/244-2015-п

Рекомендовано до публікаиії д-р пед. наук, професор Олійник В. В. Дата надходження рукопису 17.08.2015

Klyasen Nataliia, Candidate of Pedagogical Sciences, Senior Researcher, Department of project management, Institute of modernization of education content of Ministry of Education and Science of Ukraine, Metropolitan Basil Lipkivskogo str., 36, Kyiv, Ukraine, 03035

Natalia Goncharenko, Candidate of Psychological Science, Head of Education Development Strategy, Institute of modernization of education content of Ministry of Education and Science of Ukraine, Metropolitan Basil Lipkivskogo str., 36, Kyiv, Ukraine, 03035

УДК.159.92.378:036.37.10

DOI: 10.15587/2313-8416.2015.50678

\section{ПСИХОЛОГІЧНІ ОСОБЛИВОСТІ ТОЛЕРАНТНОСТІ ДО ВЗАЕМОДІї ІЗ СУБ'ЄКТАМИ НАВЧАЛЬНО-ВИХОВНОГО ПРОЦЕСУ ЯК ОДНОГО 3 КОМПОНЕНТІВ ПРОФЕСІЙНОЇ ТОЛЕРАНТНОСТІ КЕРІВНИКІВ ЗАГАЛЬНООСВІТНІХ НАВЧАЛЬНИХ ЗАКЛАДІВ}

\section{(C) О. В. Брюховецька}

Охарактеризовані показники толерантності до взаємодії із суб'єктами навчально-виховного процесу. Емпірично досліджено рівень толерантності до взаємодії із суб'єктами навчально-виховного процесу керівників загальноосвітніх навчальних закладів $і$ ї̈ показників. Зроблено висновок про необхідність розвитку толерантності до взаємодї із суб'єктами навчально-виховного процесу, як одного з важливих компонентів професійної толерантності керівників загальноосвітніх навчальних закладів, в системі післядипломної педагогічної освіти

Ключові слова: толерантності до взаємодї із суб'єктами навчально-виховного процесу, показники толерантності до взаємодії із суб'єктами навчально-виховного прочесу

The tolerance parameters to the interaction with the subjects of the educational process are characterized. The tolerance level to interaction with the subjects of the educational process by heads of secondary educational institutions and its performance is empirically investigated. The conclusion about necessity of tolerance development to the interaction with the subjects of the educational process as one of the important components of professional tolerance of heads of secondary educational institutions in the system of Postgraduate Education are made

Keywords: tolerance for interaction with educational process subjects, tolerance performance for interaction with educational process subjects

\section{1. Вступ}

Ефективність діяльності освітніх організацій в Україні в період здійснення реформ багато в чому залежить від професіоналізму і особистості керівника, який є носієм певного образу, іміджу навчального закладу, здатний забезпечити його конкурентоздатність в системі надання освітніх послуг, і фактично визначає обличчя загальноосвітнього навчального закладу, діяльність педагогічного та учнівського колективів.

Зміни вимагають орієнтації керівників загальноосвітніх навчальних закладів на толерантну взаємодію, як на базис успішного і ефективного управління. Виходячи із специфіки праці керівника загальноосвітнього навчального закладу, одним 3 найважливіших завдань, що стоять перед системою середньої освіти, є створення сприятливих умов для формування професійної толерантності як професійно важливої якості фахівців, працюючих з людьми.

Необхідно відмітити, що характеризувати сутність поняття професійної толерантності можна тільки у взаємозв'язку з поняттям іншості, або іншого (інших ідеалів, представлень, переконань і так далі), тобто того, що відрізняється від власних установок людини. Такі ситуації часто виникають в управлінській діяльності керівника, адже погляди, ідеали і спосіб життя його підлеглих можуть відрізнятися від відповідних представлень управлінця. Отже, можна сказати, що професійна толерантність є неодмінним атрибутом фахової діяльності керівників, невід'ємною ланкою в професійній взаємодії $з$ підлеглими та соціальним середовищем. Відповідно актуальним являється дослідження особливостей професійної толерантності керівників загальноосвітніх навчальних закладів та їі компонентів. 